\title{
Strategy for Acceleration of Regional Development to Reduce Unemployment and Proverty in the District of Timor Tengah Selatan-NTT
}

\author{
Deetje W. Manuain*, Nonce. F. Tuati, Hapsa Usman \\ Accounting Department \\ Kupang State of Polytechnic \\ Kupang, Indonesia \\ *decewm@yahoo.com,nonc3tuati@yahoo.com, st hapsa@yahoo.com
}

\begin{abstract}
Small and Medium Enterprises (UKM) help the community and government in providing employment, this will have a good effect in reducing the unemployment rate in Indonesia. Micro, Small, and Medium Enterprises (MSMEs) can help stabilize the Indonesian economy and assist the government in reducing unemployment, poverty, and become businesses for the income of the lower-level people. The development of MSMEs is very dependent on their competitiveness. MSMEs with high competitiveness will develop rapidly. The development of MSMEs is indeed faced with various obstacles, therefore the determination of a strategy that is suitable for business development is needed. The competition in the global era is very much determined by the advantages of the products produced. For the development of these advantages, it is necessary to develop a superior product concept. This process is carried out by identifying superior products, especially those from the small and medium enterprise sector, as a process of developing local resources and optimizing regional economic potential. The purpose of this study: 1) To identify the superior products of MSMEs in Timor Tengah Selatan Regency (TTS) to accelerate regional development and reduce unemployment and poverty. 2) To find strategies for developing MSMEs in TTS Regency in order to accelerate regional development and reduce unemployment and poverty. The research method uses a competitive profile matrix approach: this approach is aimed at assessing superior products Data Analysis Technique uses Functional Analysis, Functional analysis in this study focuses on identifying superior products, considering that MSME products have special characteristics compared to companies, EFE Analysis (External Factor Evaluation) This analysis is intended to determine how much opportunities and threats are faced by MSMEs, IFE (Internal Factor Evaluation) analysis: this analysis is intended to determine how much strengths and weaknesses MSMEs are, SWOT analysis (Strength, Weakness, Opportunity, And Threats): To determine the strengths, weaknesses, opportunities, and threats faced by MSMEs, the sample in this study amounted to 25 MSMEs. Based on the identification of the superior products of MSMEs in TTS Regency, the leading SME sector to be developed is the agriculture, forestry and fisheries sector with the magnitude of the LQ index value is 4.32. Furthermore, the SME development strategy is the ST strategy,
\end{abstract}

which is a strategy to use strength to overcome threats. With this strategy, SMEs should maintain product brand image in the eyes of consumers by focusing on quality, maintaining product diversification, maintaining cooperation with raw material suppliers and establishing good relationships with local raw material suppliers, then SMEs should innovate products, pay attention to the welfare of workers, increase relations or cooperation with external parties such as banks and companies outside TTS and the government gives more attention to SMEs.

Keywords-strategy, regional development acceleration, unemployment, poverty

\section{INTRODUCTION}

The development of SMEs is crucial, considering that SMEs have such an essential role in the economic growth, including Indonesia [1]. To date, the dominant business actors in East Nusa Tenggara (NTT) are micro, small, and medium enterprises (MSMEs). As stated by the Head of Cooperative and Business, Micro, Small and Medium Enterprises (MSME) NTT Province, Paulus R Tadung, said, "The current economic activity tends to increase and which is quite prominent in the field of MSMEs ". MSMEs have been able to show relatively more resilient performance in the face of a prolonged crisis period [2].

Small and Medium Enterprises (SME) help the community and government provide employment; this will have a good effect on reducing the unemployment rate in Indonesia. MSMEs can help stabilize the Indonesian economy and help the government reduce unemployment, poverty, and become efforts for the income of lower-level people. In 2017, the number of MSMEs in Indonesia was recorded at 59.6 million units or $99.99 \%$ of the total existing economic business units, with a labor absorption rate of $88.7 \%$ of the total workforce or 68.28 million people [3]. This data indicates that MSMEs can be a driving force for national economic growth. Seeing the various problems faced in the development of SMEs, it is necessary to have an SME development strategy so that the development of SMEs in Indonesia can dash, the problems 
faced by SMEs can be reduced, and SMEs have the advantage of being more competitive in money [4].

The advantages of the products produced very much to determine the competition in the global era [5]. In the context of developing these advantages, it is necessary to develop a superior product concept. The superior product concept process is carried out by identifying superior products, especially those from the small and medium business sectors, to develop local resources and optimize regional economic potential. Superior products are also competitive, market-oriented, and environmentally friendly, to create a competitive advantage that is ready to face global competition [6]. The competitive advantage is superiority and or higher differentiation compared to competitors' bids [7]. The exploration of regional potential needs to be optimized under the demands of regional autonomy to increase Local Government Revenue.

Referring to the urgency of identifying superior products in the regions related to the implementation of regional autonomy and their relevance to the absorption of local economic bases to spur Local Government Revenue and employment, identifying superior products is becoming increasingly interesting for further study [8]. The development of MSMEs can increase labor absorption so that unemployment and poverty can be reduced. In connection with poverty reduction and unemployment policies, the government has been trying to build and empower MSMEs in Indonesia. One form of these efforts is by calling for an increase in the amount of credit given to MSMEs; the goal is that the existence of MSMEs in the future will grow to help poverty reduction and unemployment programs in Indonesia. Many studies have shown that unemployment can be dangerous in several ways, financially and psycho-socially, and health. Unemployment is linked to mental and physical health and mortality [9].

One of the government's strategies supporting economic development and regional development is empowering and growing Micro, Small, and Medium Enterprises (MSMEs) as the basis for populist economic development. History has shown that MSMEs in Indonesia still exist and thrive despite the economic crisis. The development of MSMEs can be an effective strategy in regional economic development, especially in underdeveloped areas or have economic imbalances against other regions/regions such as NTT, especially in Timor Tengah Selatan (TTS) - NTT.

The development of MSMEs is very dependent on the competitiveness they have [10]. MSMEs with high competitiveness will develop rapidly. The development of MSMEs is facing various obstacles; therefore, the determination of a suitable strategy for business development is needed. This research will identify the superior products of Micro, Small, and Medium Enterprises (MSMEs) and the MSME Development Strategy in Timor Tengah Selatan (TTS) - NTT to accelerate regional development reduce unemployment and poverty.

This study aims to identify superior products (MSMEs) in Timor Tengah Selatan (TTS) - NTT to accelerate regional development and reduce unemployment and poverty and to find strategies for developing MSMEs in Timor Tengah Selatan (TTS) - NTT to accelerate regional development and reduce unemployment and poverty.

distance education for higher education faces five significant challenges: infrastructure, the cost, the relevance of the curriculum, inadequate expertise in distance education, and poor attitudes towards distance learning [5]. Consequently, this research will try to determine internal and external factor analysis summary (strengths, weaknesses, opportunities, and threats) of e-teaching implementation for lecturers and institutions to determine the future of e-teaching strategies. The research questions of the study have been formulated as:

- What are the strengths and weaknesses of e-teaching implementation at the Kupang State of Polytechnic in online teaching?

- What are the opportunities and threats of e-teaching implementation at the Kupang State of Polytechnic in online teaching?

- How to determine the e-teaching implementation strategy at the Kupang state of Polytechnic in the future?

\section{METHODS}

The processing and analysis method is a quantitative descriptive analysis. The data sources are secondary data and primary data, while the types of data to be used are descriptive analysis and Chi-square analysis, which is done using the frequency distribution method. The population in this study was Small and Medium Enterprises; the sample in this study is 25 MSMEs. The data analysis technique uses Location Quotient (LQ). Miller and Wright [11], Isserman [12], and Hood [13] suggest that the Location Quotient (LQ) method is used to identify superior commodities in a region. The LQ technique is one of the approaches commonly used in basic economic models as a first step to understanding the sectors of activity that are driving growth. This technique provides a relative comparison between a sector's capabilities in the area under investigation with the same capabilities in the broader area. The units used to produce the LQ coefficient are the amount of labor, output, or other units that can be used as criteria

If you use the production value as a consideration in calculating LQ, LQ is greater than 1 (LQ> 1), meaning that the commodity is a base sector. LQ is smaller than 1 (LQ <1), which means that these commodities' production is not sufficient for consumption needs in the region concerned, and the fulfilment is imported from other regions. LQ is equal to 1 $(\mathrm{LQ}=1)$, meaning that the commodity's production is only sufficient for local needs.

The LQ formula based on the consideration of the GRDP value is as follows: 


$$
L Q=\frac{V_{x}^{R} / V^{R}}{V_{x}^{\mathrm{N}} / V^{\mathrm{N}}}
$$

Where:

$V_{x}^{R}=$ total GRDP in a sector $\mathrm{x}$ in area $\mathrm{R}$

$V^{R}=$ total GRDP of all sectors in area $\mathrm{R}$

$V_{x}^{W}=$ total GRDP in a sector $\mathrm{x}$ in the reference area $\mathrm{N}$

$\mathrm{V} \mathrm{N}=$ total GRDP of all sectors in the reference area $\mathrm{N}$

The strengths, weaknesses, opportunities, and threats faced by MSMEs.

SWOT analysis (Strength, Weakness, Opportunities, Threats) is commonly used to evaluate opportunities and challenges in the business environment and the company's internal environment [14]. A SWOT matrix construction is required to facilitate the implementation of a SWOT analysis by combining the strengths, weaknesses, opportunities, and threats. The SWOT matrix is illustrated in Table 1.

TABLE I. SWOT ANALYSIS MATRIX

\begin{tabular}{|l|l|l|}
\hline Internal Factor & $\begin{array}{l}\text { Strengths (S) } \\
\text { (List of } \\
\text { Strengths) }\end{array}$ & $\begin{array}{l}\text { Weaknesses (W) } \\
\text { (List of } \\
\text { Weaknesses) }\end{array}$ \\
\hline $\begin{array}{l}\text { Opportunities (O) } \\
\text { (list of All identified } \\
\text { Opportunities) }\end{array}$ & $\begin{array}{l}\text { Strategy SO } \\
\text { (Growth) }\end{array}$ & $\begin{array}{l}\text { Strategy WO } \\
\text { (Stability) }\end{array}$ \\
\hline $\begin{array}{l}\text { Threats (T) } \\
\text { (List of all identified Threats) }\end{array}$ & $\begin{array}{l}\text { Strategy ST } \\
\text { (Diversification) }\end{array}$ & $\begin{array}{l}\text { Strategy WT } \\
\text { (Defend) }\end{array}$ \\
\hline
\end{tabular}

From the SWOT analysis matrix as presented in Table 1, it can be identified that there are 4 (four) strategies, namely: First, the SO strategy, which is a strategy to use all available strengths to take advantage of current opportunities. Second, the WO strategy is a strategy to overcome all weaknesses by taking advantage of existing opportunities. Third, the ST strategy is a strategy of using all strength to avoid all threats. Fourth, the WT strategy, which is a strategy to suppress all weaknesses and prevent all threats.

These three approaches developed in the research: a) identify the advantages of MSME products with the most potential to be developed. The LQ index will be used as a guide to identifying the advantages of these SME products, $b$ ) identify MSME problems, c) strategic planning using a SWOT analysis matrix approach, d) analysis of SME business development strategies, e) proposals for implementing strategies.

\section{RESULTS AND DISCUSSION}

\section{A. Identification of the Advantages of UMKM Products}

There are 9 (nine) SME economic sectors that will be developed, namely: a) agriculture, forestry and fisheries, b) mining and quarrying, c) processing industry, d) electricity, e) $\mathrm{ga}$, and clean water, f) buildings, g) hotel and restaurant trade, h) transportation and communication and i) other services. LQ index is used to determine the leading SME sector from these 9 sectors. The calculation and analysis of LQ were based on comparing the GRDP data of each SME sector with the accumulated GRDP data for all sectors in East Timor Tengah Selatan (TTS) NTT. The GRDP value on which the calculation is based is used the GRDP value at constant prices. The results of the calculation of the LQ value in the form of an index value presented in Table 2. Based on the results of the calculations presented in Table 2, the SME sector which is the leading sector to be developed were the agriculture, forestry, and fisheries sector with the magnitude of the LQ index value was 1.44. The LQ index value of the agriculture, forestry, and fisheries sector SMEs was the largest among the indexes of other sectors.

Thus, based on the LQ index value, it can be concluded that SMEs in the agricultural, forestry, and fisheries sectors have the most potential to continue to be developed.

TABLE II. SWOT INDEX LQ SECTOR SME

\begin{tabular}{|l|l|}
\hline \multicolumn{1}{|c|}{ Sector } & Index LQ \\
\hline Agriculture, Animal Husbandry, Forestry and Fisheries & 4,32 \\
\hline Mining and Quarrying & 0,19 \\
\hline Processing Industry & 0,07 \\
\hline Procurement of electricity, gas and clean water & 0,01 \\
\hline Building & 1,15 \\
\hline Trade, Hotel and Restaurant & 0,73 \\
\hline Transportation and Communication & 1,01 \\
\hline Finance, Leasing and company services & 0,3 \\
\hline Other Services & 2,22 \\
\hline
\end{tabular}

The characteristics of SMEs that have competitive advantages are as follows: a) have good quality human resources, b) optimal use of technology, c) can make efficiency and increase productivity, d) can improve product quality, e) have broad access promotion, f) has a structured quality management system, g) adequate capital resources, h) has a comprehensive business network, and i) has an entrepreneurial spirit [15].

\section{B. Identification of UMKM Problems}

MSMEs in Timor Tengah Selatan (TTS) district as one of the strong economic foundations and accelerating regional development in Timor Tengah Selatan (TTS) district still have several problems in their development. The problems faced in the development of UMKM are;

- Limited business capital as a result, entrepreneurs cannot increase their production volume to achieve more turnover. many MSME players have difficulty obtaining additional capital from financial institutions because of the many unfulfilled requirements.

- Human Resources are the main problem for MSMEs. With capable human resources, creative and innovative steps will be created for the sustainability of their business 
- Tax payments that are often ignored by MSME actors. This shows that not all MSME actors understand how to calculate the taxes that are their obligations.

- In matters of licensing, MSMEs do not have official business permits so that it hinders the pace of business, one of which is when they want to apply for capital.

- Lack of innovation, many MSMEs are running in developing their businesses because of the lack of innovation. Finally, many businesses only last for 1-2 years, then go bankrupt because the products or services offered are not strong or cannot compete.

- Distribution and marketing for MSMEs experience problems due to reduced networking/working relationships and proper marketing techniques from MSME business actors

- Technology, the current technological developments bring many benefits to MSME players, not only in marketing their products but also in facilitating MSME players' production process. The presence of marketplace and social media channels opens opportunities for MSME players to introduce their products to a broader realm.

The problems faced by SMEs are summarized as follows: a) lack of capital, b) difficulties in marketing, c) simple organizational structure with the non-standard division of labor, d) low management quality, e) limited human resources and quality low, g) most of them do not have financial reports, h) weak legality aspects, and j) low quality of technology. These problems result in weak business networks, limited ability to market penetration and market diversification, too small economies of scale, so that it is challenging to reduce costs, minimal profit margins, and SMEs do not have a competitive advantage $[16,17]$. technology simulation can be introduced to help farmers protect and increase their yields [1820].

\section{Strategic Planning with a SWOT Analysis Matrix Approach}

The SWOT analysis matrix is a method capable of designing strategies according to internal conditions which include strengths and weaknesses as well as external conditions which include opportunities and threats faced by MSMEs. The analysis matrix compares every aspect of internal and external conditions to produce a strategy. The alternative strategies generated by the SWOT matrix can be seen in Table 3 .

\section{TABLE III. ALTERNATIVE SWOT STRATEGIES}

\begin{tabular}{|l|l|}
\hline No & \multicolumn{1}{|c|}{ Strategy Alternative } \\
\hline 1 & $\begin{array}{l}\text { Maintain product brand image in the eyes of consumers through } \\
\text { focus on quality }\end{array}$ \\
\hline 2 & Excellent product diversification \\
\hline 3 & $\begin{array}{l}\text { Maintain cooperation with farmers in the procurement of raw } \\
\text { materials }\end{array}$ \\
\hline 4 & Taking care of the legality of SMEs \\
\hline
\end{tabular}

The SWOT analysis conducted in TTS is in the Agriculture, Animal Husbandry, Forestry, and Fisheries sectors. Research showed a SWOT analysis of agriculture in the Republic of Serbia. The author studies the capacity, conditions, and productivity of the agricultural industry. The research used statistical tools to assess the evolution of certain production factors such as resources (labor, land, and livestock), productive yields (yields and total production of essential crops), and economic yields (domestic products from agriculture). However, the study failed to include assessment infrastructure, the role of government, and policy implications; the part of competing sectors, industry and trade, is not analyzed, but it is necessary to remember the fact that the scope of their activities is highly dependent on agriculture [21].

\section{Analysis of SME Business Development Strategies}

There are 4 (four) analysis of strategies proposed for SMEs according to the level of strategic significance to their business development. However, 3 strategies were prioritized.

The analysis of the proposed strategies for SMEs is as follows:

1) Maintain product brand image in the eyes of consumers through a focus on quality: This strategy aims to enable SMEs to maintain their existence in order to meet domestic needs. This may be done by SMEs in TTS because they have strengths including good product quality. In addition, this strategy can become a mainstay for competing with foreign products due to the policies implemented by the government regarding the ASEAN economic community.

2) Product diversification: This strategy aims to optimize the resources available to SMEs. In addition, this strategy is able to become a competitive solution with substitute products that are increasingly numerous and have low prices.

3) Taking care of the legality of SMEs: This strategy aims to enable SMEs to develop their businesses and have a legal basis for business establishment. This strategy is possible for SMEs and government programs that support SMEs to develop. This strategy is able to increase the capital of SMEs through programs carried out by the government and private banks. Legality is also able to increase consumer confidence in SMEs because they are considered professional.

\section{E. Proposed Implementation of the Strategy}

The action plans and actions that must be taken on the proposed strategy to be implemented for SMEs are as follows:

1) Maintain product brand image in the eyes of consumers through a focus on quality: Including: a) Ensuring the availability of raw materials, b) Checking raw materials and supporting materials to comply with SME standards, c) Provide training on quality standards to employees, d) Implementing SME operational standards in the production process, e) Accept and implement suggestions suggested by 
consumers, f) Simplify communication between producers and consumers.

2) Product diversification: To take advantage of machine utilities including: a) Improve relationships with local raw material suppliers b) Conduct training on the processing process, c) Create operational standards regarding SME products, d) Build relationships with new customers.

3) Taking care of the legality of SMEs: This strategy aims to enable SMEs to develop their businesses and have a legal basis for business establishment including: a) Fulfill the requirements related to the legality formation of SMEs, b. Conduct training on SME management.

\section{CONCLUSION}

In conclusion, the strategy for developing a business that is appropriate to the conditions of SMEs in TTS Regency is as follows: maintain product brand image in the eyes of consumers through a focus on quality, product diversification, taking care of the legality of SMEs, maintain cooperation with suppliers of raw materials, maintain good relationships with local suppliers of raw materials.

\section{ACKNOWLEDGMENT}

This study was supported by DIPA funding from the Kupang State of Polytechnic. We gratefully thank you for the financial support. We thank Nonce F. Tuati as the director of Kupang State of Polytechnic.

\section{REFERENCES}

[1] S. Husband and M.A. Purnendu, "Conceptual Model for Quality Inetgrated Management in Small and Medium Size Enterprise,' International Journal of Quality \& Reliability Management, vol. 16, no. 7, pp. 699-713, 1999.

[2] Pos Kupang, Harian Umum Nusa Tenggara Timur, vol. may $3^{\text {rd }}, 2017$.

[3] BPS Provinsi Nusa Tenggara Timur, Dalam Angka, 2017.

[4] M.J. Hafsah, Upaya Pengembangan Usaha Kecil dan Menengah (UKM), Infokop Nomor 25 Tahun XX, pp 40-44, 2004.
[5] J. Heryanto, Peranan multinational corporations dalam industrialisasi di Indonesia, 2003

[6] M.E. Porter, Competitive Advantage of Nations. Mass: Free Press, Canada, 1990 .

[7] D.H. Henard and D.M. Szymanski, "Why some new products are more successful than others," Journal of Marketing Research, vol. XXXVIII, 2001.

[8] M. Maulud, Identifikasi sektor unggulan dan prioritas pembangunan ekonomi di Kabupaten Merauke, Propinsi Papua, Tesis Program Studi Magister Ekonomika Pembangunan, Yogyakarta: UGM, 2004.

[9] V. Katrien and G. Sylvie, "Unemployment and cause-specific mortality among the Belgian working-age population,” Journal Pone, 2019.

[10] H. Haeruman, Peningkatan Daya Saing Industri Kecil, Jakarta: Graha Sucofindo, Jakarta. 2000.

[11] M.M. Mille and G.N. Wright, "Location Quotient Basic Tool for Economic Development Analysis,” Economic Development Riview, vol. 9 , no. 2,1991

[12] A.M. Isserman, The Location Quotient Approach for Estimating Regional Economic Impacts, AIP Journal, 1997.

[13] Hood, Economic Analysis: A Location Quotient, Primer, Principal Sun Region Associates, Inc., 1998

[14] M. Kuncoro, Strategi: Bagaimana Meraih Keunggulan Kompetitif?, Jakarta: Erlangga, 2005.

[15] T. Tambunan, Usaha Kecil dan Menengah di Indonesia: Beberapa Isu Penting, Jakarta: Salemba, 2002

[16] E.S. Winarni, Strategi Pengembangan Usaha Kecil melalui Peningkatan Aksesibilitas Kredit Perbankan, Infokop Nomor 29, Tahun XXII, 2006.

[17] J. Situmorang, Strategi UMKM dalam Menghadapi Iklim Usaha yang Tidak Kondusif, Infokop, vol. 16, pp. 88-101, 2008.

[18] F. Nweke. "New challenges in the cassava transformation in Nigeria and Ghana," EPTD Discussion paper no. 118. Environment and Production Technology Division International Food Policy Research Institute 2033 K Street, NW Washington, D.C. 20006 USA, Tahun 2004

[19] S. Odebode. "Appropriate technology for cassava processing in Nigeria: User's point of view," Journal of International Women's Studies, vol. 9 no.3, May 2008

[20] O. Oluwasola. "Stimulating rural employment and income for cassava (Manihot sp.) processing farming households in Oyo State, Nigeria through policy initiatives," J. Dev. Agric. Econ., Vol. 2, no. 2, pp. 018025, Feb. 2010

[21] N. Novkovie. SWOT analysis of agriculture in the republic of Serbia 2008 . 